\title{
Risk factors associated with short-term post-treatment outcomes of clinical mastitis
}

\author{
C. Pinzón-Sánchez and P. L. Ruegg ${ }^{1}$ \\ Department of Dairy Science, University of Wisconsin, Madison 53706
}

\begin{abstract}
The objectives of this study were to characterize 60-d outcomes after treatment of mild (abnormal milk) and moderate (abnormal milk and abnormal udder) cases of clinical mastitis (CM) occurring in a single quarter of cows on Wisconsin farms $(n=4)$ and to determine risk factors associated with those outcomes. Duplicate milk samples were collected from the affected quarter of each cow for microbiological analysis at the onset of $\mathrm{CM}$ (PRE) and $21 \mathrm{~d}$ later (POST). Cows were treated only in the affected quarter using an intramammary product containing $125 \mathrm{mg}$ of ceftiofur. Bacteriological cure was defined as absence of pathogens in the POST sample obtained from the enrolled quarter. Recurrence was defined for the cow when CM occurred after the milk-withholding period for the enrolled case of CM. Retention in the herd was defined when a cow was retained within the herd for the 60-d follow-up period. Somatic cell count reduction (SCCR) was defined at the cow level as somatic cell count (SCC) below 200,000 cells/mL at the Dairy Herd Improvement Association test day occurring between 21 to 55 d posttreatment. The effects of farm, days in milk, parity, severity, microbiological diagnosis at PRE, previous milk yield, previous SCC, previous occurrence of CM and treatment duration on selected post-treatment outcomes were assessed using Chi-squared analysis and logistic regression. Microbiological results at PRE were distributed as: Escherichia coli $(\mathrm{n}=14)$, Klebsiella spp. $(\mathrm{n}=11)$, Enterobacter spp. $(\mathrm{n}=8)$, Serratia spp. $(\mathrm{n}=$ $7)$, other gram-negative species $(\mathrm{n}=3)$, Streptococcus spp. $(\mathrm{n}=25)$, coagulase-negative staphylococci ( $\mathrm{n}=$ 4); Staphylococcus aureus $(\mathrm{n}=1)$; Streptococcus agalactiae $(\mathrm{n}=1)$, other gram-positive species $(\mathrm{n}=9)$, and culture negative $(\mathrm{n}=60)$. Treated quarters were more likely to experience bacteriological cure when the cow experienced CM for the first time in the lactation and when no pathogen was recovered from PRE milk samples obtained from the enrolled quarter. Parity and
\end{abstract}

Received October 11, 2010.

Accepted March 23, 2011.

${ }^{1}$ Corresponding author: plruegg@wisc.edu bacteriological cure were associated with the probability of recurrence. Greater milk yield at previous Dairy Herd Improvement test was the most important predictor for retention within the herd. When SCC before CM was $>200,000$ cells $/ \mathrm{mL}$ the probability of having SCCR after treatment was decreased. When the case experienced bacteriological cure, the cow was less likely to experience recurrent cases and was more likely to have SCCR below 200,000 cells/mL. Post-treatment outcomes, such as recurrence and SCCR, are strongly associated with bacteriological cure and, when monitored, can be used to help determine if a treatment has been successful. Information about the etiology of CM, history of clinical and subclinical mastitis, and parity are useful to review when making strategic treatment decisions.

Key words: mastitis, treatment, dairy, milk quality

\section{INTRODUCTION}

In the United States more than $90 \%$ of cows affected with clinical mastitis (CM) are treated with antimicrobials (Hill et al., 2009) and treatment of mastitis accounts for the majority of antimicrobials used to treat adult dairy cows (Pol and Ruegg, 2007). Effective treatment of $\mathrm{CM}$ depends on different factors related to the cow, the pathogen, and the drug used for treatment. Cow factors associated with treatment efficacy include age, stage of lactation, effectiveness of the cow's immune response, SCC, and number of infected quarters (Sol et al., 2000; Constable and Morin, 2003; Deluyker et al., 2005; Bradley and Green, 2009). Pathogen factors include pathogenicity, virulence, and response to antimicrobial therapy (Pyörälä and Pyörälä, 1998; Sol et al., 2000; Constable and Morin, 2003; Barkema et al., 2006; Bradley and Green, 2009). Drug factors include spectrum of activity, route of administration, concentration of the drug that can be maintained at the site of infection, and duration of treatment (Constable and Morin, 2003; Bradley and Green, 2009). Better understanding of factors associated with successful therapeutic outcomes would help producers make better treatment decisions and select $\mathrm{CM}$ cases that are more likely to respond to treatment. 
As farms have increased in size, it often seems that some managers of large dairy farms evaluate only apparent short-term results of treatments rather than the overall effect on the entire lactation. Clinical cure, bacteriological cure, number of days milk is not saleable, recurrence of $\mathrm{CM}$, retention of the animal within the herd, SCC, and milk production have all been discussed as indicators of treatment success (Guterbock et al., 1993; Hoe and Ruegg, 2005; Milne et al., 2005; Wenz et al., 2005; Bar et al., 2007; McDougall et al., 2007; Apparao et al., 2009; Lago, 2009; Schukken et al., 2009). Several researchers have reported factors affecting outcomes of treatment of subclinical mastitis (Owens et al., 1988; Sol et al., 1997; Deluyker et al., 2005) but fewer studies have been published about risk factors affecting short-term outcomes of clinical mastitis therapy.

Criteria for determination of successful treatment of CM are often difficult to establish. Outcomes such as clearance of pathogens (as assessed by bacteriological cure), the immunological response to apparently healthy levels of SCC $(<200,000$ cells $/ \mathrm{mL})$, the decrease in recurrent cases of $\mathrm{CM}$, and retention of the cow in the herd are all potentially important indicators of treatment success. Treatment strategies such as use of antimicrobials for various durations, discard of abnormal milk without antimicrobial treatment, culling of cows that are unlikely to respond to therapy, drying off the affected mammary gland or drying off the cow may be recommended, depending on the probability of reaching a successful outcome. More information about risk factors that influence important post-treatment outcomes is needed to help farmers appropriately treat CM and decrease unnecessary use of antimicrobials. The objectives of this study were to describe selected post-treatment outcomes of mild and moderate cases of $\mathrm{CM}$ and to determine risk factors associated with those outcomes.

\section{MATERIALS AND METHODS}

\section{Herd and Cow Enrollment Criteria}

Wisconsin dairy herds $(\mathrm{n}=4)$ participated in the study between November 2008 and August 2009. Herds were required to use computerized animal health records, participate in monthly DHIA milk testing, actively use an on-farm culture program, and use a complete milking routine that included fore-stripping for detection of mastitis.

For each single quarter case, clinical mastitis was classified according to severity of the symptoms as mild (the only symptom was abnormal appearance of milk), moderate (abnormal appearance of milk accompanied by swelling or redness of mammary gland), or severe (cow exhibited systemic signs of illness). All cases of $\mathrm{CM}$ were recorded, but only lactating dairy cows presenting mild or moderate cases of clinical mastitis occurring in a single mammary quarter were eligible for enrollment. Each cow was eligible for enrollment only once. Each herd enrolled cases until about 50 eligible cases were obtained. Cases involving multiple quarters, cows presenting severe symptoms, and cows that had been treated with antimicrobials during the $14 \mathrm{~d}$ preceding detection of the case were excluded.

\section{Sampling and Data Collection}

Farm personnel were trained to classify severity of $\mathrm{CM}$ and to aseptically collect duplicate quarter milk samples only from the affected quarter before initiating treatment (PRE) according to individual farm protocols. Farm personnel collected another set of duplicate quarter milk samples from the enrolled quarter approximately $21 \mathrm{~d}$ (14-44 d) after each case was enrolled (POST). Study personnel collected standardized data for each case at enrollment and during a 60-d follow-up period.

\section{Microbiological Analysis}

Frozen milk samples were picked up by study personnel during weekly or biweekly farm visits and transported to the Milk Quality laboratory at the University of Wisconsin-Madison. Milk samples were thawed at room temperature and $100 \mu \mathrm{L}$ of milk from each duplicate sample was inoculated onto each half of a blood agar plate. MacConkey agar plates were divided into quarters and $10 \mu \mathrm{L}$ of milk from each duplicate quarter sample were streaked onto each quarter. Plates were incubated at $37^{\circ} \mathrm{C}$ for 24 to $48 \mathrm{~h}$. Weekly samples from each farm were pooled and $100 \mu \mathrm{L}$ were inoculated on mycoplasma culture medium (Media Laboratory, School of Veterinary Medicine at the University of California. Davis, CA) and incubated in $6 \% \mathrm{CO}_{2}$ at $37^{\circ} \mathrm{C}$ for up to $14 \mathrm{~d}$. Microbiological analysis was performed according to National Mastitis Council guidelines (NMC, 1999).

Isolates that grew on MacConkey agar underwent further identification using Gram stain, and inoculation on triple sugar iron slants, motility, indole and ornithine, and sodium citrate slants. Speciation of Streptococcus and Staphylococcus species was done using commercial API system tests (bioMérieux Vitek, Inc. Durham, NC). When no growth was observed after $24 \mathrm{~h}$ of incubation on either agar, refrigerated milk samples were incubated for $6 \mathrm{~h}$ at $37 \mathrm{C}$ and $1 \mathrm{~mL}$ of milk was inoculated on Petrifilm Staph Express (3M, St. Paul, MN). Confirmation of Staphylococcus aureus was based on presence of a distinct pink zone around 
Table 1. Criteria used to define diagnosis of cases based on microbiological results from duplicate milk samples (A and B) for pre-treatment (PRE) and post-treatment (POST) milk samples obtained from mild and moderate cases of clinical mastitis

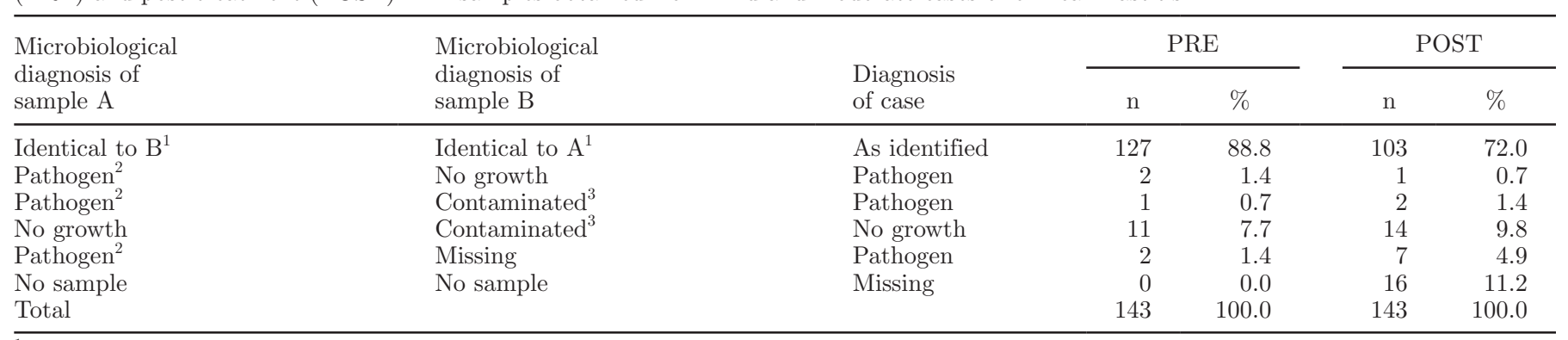

${ }^{1}$ Pathogen, no growth, or contamination.

${ }^{2}$ Isolation of at least 3 colonies of the same type of bacteria.

${ }^{3}$ Isolation of 3 or more different colony types.

suspect colonies after application of a DNase disk (Silva et al., 2005).

A variety of definitions of IMI are used in mastitis research (Andersen et al., 2010) and because environmental pathogens were most prevalent in this group of herds, an IMI was defined as the isolation of at least $300 \mathrm{cfu}$ of the same type of bacteria from milk samples. Mixed infection was defined as the isolation of at least 3 colonies of 2 different types of bacteria from milk samples. Contamination was defined as the isolation of 3 or more different colony types from milk samples. Results of each duplicate quarter milk sample were compared with a final case diagnosis (Table 1). Data from quarters with nonsignificant growth $(<300 \mathrm{cfu})$ were combined with no growth for analysis.

\section{Definitions}

Days until clinical cure was defined as the number of days until the milk returned to normal appearance. Days of milk discarded was defined as the number of days the milk was not eligible for sale, including days of treatment and withholding period of the drug. Microbiological outcomes of PRE milk sample were categorized as gram-positive, gram-negative, or no growth. Bacteriological cure was assessed by comparing microbiological results of PRE and POST milk samples. Bacteriological cure was defined as absence of pathogens in the POST milk sample, regardless of recovery of a causative pathogen isolated in the PRE milk sample. When a pathogen was recovered in the PRE milk sample but the POST milk sample was culture negative, the outcome was defined as a treatment cure, whereas when no pathogens were recovered from either the PRE or POST milk samples, the outcome was defined as a spontaneous cure. Quarters with either treatment cure or spontaneous cure were classified as experiencing bacteriological cure. An enrolled quarter was classified as not experiencing bacteriological cure when any pathogen (or mixed infection) was present in the POST milk sample. A new infection was defined when a different pathogen (as compared with the PRE milk sample) was obtained in the POST milk sample or when no pathogen was recovered in the PRE but a pathogen was recovered in the POST milk sample. Treatment failure was defined when the same pathogen was present in both the PRE and POST milk samples. Enrolled quarters with either new infection or treatment failure were classified as not experiencing bacteriological cure. Recurrence of clinical mastitis during the 60-d follow-up period was defined as the occurrence of a case of clinical mastitis in any quarter of the same cow, after the end of the milk-withholding period for the enrolled case. Retention within the herd during the 60-d follow-up period was defined as cows remaining in the herd (lactating or dry), as opposed to leaving the herd because of sale or death. Somatic cell count reduction (SCCR) was defined at the cow level as SCC below 200,000 cells/mL at the DHIA test day occurring between 21 to $55 \mathrm{~d}$ post-treatment.

\section{Statistical Analysis}

Statistical analyses were carried out using SAS 9.2 (SAS Institute, 2008). Statistical analysis was performed only for animals treated solely in the clinically affected quarter using a commercially marketed intramammary (IMM) product containing $125 \mathrm{mg}$ of ceftiofur and with a microbiologic diagnosis of gram-positive, gram-negative, or no growth.

The effect of selected risk factors (explanatory variables) on post-treatment outcomes (response variables) was tested using logistic regression. Dichotomous outcomes evaluated were: bacteriological cure, recurrence, retention within the herd, and SCCR below 200,000 cells $/ \mathrm{mL}$. The explanatory categorical variables used 
in statistical models were farm $(\mathrm{A}, \mathrm{B}, \mathrm{C}$, or $\mathrm{D})$, parity group $(1,2,3$, or $>3)$, severity (mild or moderate), previous occurrence of CM (yes or no), and microbiological diagnosis at PRE (gram-positive, gram-negative, or no growth). The explanatory continuous variables used in statistical models were DIM at occurrence of CM case, SCS at previous DHIA test, milk production $(\mathrm{kg} /$ cow per day) at previous DHIA test, and duration of antimicrobial treatment (d).

Logistic regression with generalized estimated equations was used to assess potential correlation of outcome observations within farm (Palta, 2003) using the GENMOD procedure. All individual outcome variables from the same farm were poorly correlated $(\mathrm{r}=-0.02)$ and as a result, the simpler model considering independence among outcome observations provided the best fit for the data.

All explanatory variables were subjected to univariate analyses by means of Chi-squared or ANOVA tests using the PROC FREQ, PROC ANOVA, and PROC GLM procedures. Variables, as well as their interaction terms, with a $P$-value $<0.25$ in a univariate analysis were offered into the multivariate models. Multivariate analyses were assessed using PROC LOGISTIC.

Six separated logistic regression models were built to assess the effect of selected risk factors on posttreatment outcomes. Four models (one model for each post-treatment outcome; model 1), included information that is commonly available for producers. Two additional models (one for recurrence and one for SCCR; model 2) included information about bacteriological cure. The effect of farm was forced in the models for recurrence and retention because detection of clinical mastitis and culling policies vary among farms. Final models were selected based on biological significance and comparison of model fit statistics after using forward selection and backward elimination procedures. Goodness of fit was assessed using the Hosmer and Lemeshow test of PROC LOGISTIC.

\section{RESULTS}

\section{Herd Characteristics}

Participating herds ranged in size from 640 to 1,250 cows and contained almost entirely Holstein cattle (Table 2). The average milk production was $40.2 \mathrm{~kg} /$ cow per day and bulk tank SCC was 218,000 cells/mL (Table 2). After enrolling in the study, herd managers were asked to enroll the next 50 cases of mild or moderate $\mathrm{CM}$ and the time required to acquire those cases ranged from 31 to $101 \mathrm{~d}$ (Table 2). All cows were milked 3 times per day using a complete milking routine consisting of stripping of foremilk, pre- and post- dipping disinfection and drying of teats. All lactating cows were housed in freestall barns bedded with sand $(\mathrm{n}=3)$ or recycled manure $(\mathrm{n}=1)$ and were fed a TMR. Use of core-antigen coliform vaccination (3 to 4 times during the lactation) as part of herd health program was reported by all herds.

\section{Characteristics of Clinical Mastitis}

All cases of CM ( $\mathrm{n}=266$ cases occurring in 266 cows), including those with severe symptoms $(\mathrm{n}=22)$, that occurred during the sampling period were recorded. The proportions of CM cases with mild, moderate, and severe symptoms were $65 \%, 27 \%$, and $8 \%$, respectively (Table 2). Of initial mild and moderate cases $(\mathrm{n}=244)$, 11 cows were excluded because of multiple affected quarters or antimicrobial treatment within $14 \mathrm{~d}$. Of the remaining 233 mild and moderate cases, cases were excluded because the PRE sample was contaminated (n $=21)$, the case was caused by a mixed infection $(\mathrm{n}=$ $5)$, samples were missing $(\mathrm{n}=3)$, the cow did not receive antimicrobial treatment $(\mathrm{n}=30)$, or the cow was treated with protocols other than IMM ceftiofur $(\mathrm{n}=$ 31). All farms enrolled in the study used IMM ceftiofur for treatment of mild and moderate cases of CM. Farms $\mathrm{A}, \mathrm{B}$, and $\mathrm{C}$ used ceftiofur for treatment of most cases $(75 \%, 100 \%$, and $70 \%$, respectively), whereas farm D used it in only $43 \%$ of the cases. The decision to use intramammary treatments on farm D was not based on selection of specific case criteria but was determined by farm personnel based on available space in the hospital pen. When the hospital pen was full, this farm did not administer mastitis treatments to additional affected cows. Only data obtained from 143 cases of CM that occurred in cows that received IMM treatment with ceftiofur and had microbiological diagnosis of grampositive, gram-negative, or no growth were used for the rest of the statistical analysis (Table 2).

\section{Population Characteristics}

Of cases included in statistical analysis $(\mathrm{n}=143)$ most occurred in multiparous cows (85\%) compared with primiparous cows (15\%), and a greater proportion exhibited mild as compared with moderate symptoms (Table 2). Almost $60 \%$ of cases occurred in front quarters. Seventy percent of cows did not have a history of previous cases of CM within the studied lactation (Table 2). The occurrence of previous cases was associated with farm $(P=0.029)$, DIM at occurrence of CM $(P$ $<0.001)$, milk production $(P<0.001)$, and SCS at the previous DHIA test $(P<0.001)$. The average DIM at enrollment was $152 \mathrm{~d}$ and was not associated with farm $(P=0.621)$ or severity of the case $(P=0.393$; Table 3$)$. 
Table 2. Characteristics of herds, cows, and cases of clinical mastitis (CM)

\begin{tabular}{|c|c|c|c|c|c|c|c|c|c|c|c|c|}
\hline \multirow[b]{3}{*}{ Variable } & \multicolumn{8}{|c|}{ Farm } & \multirow[b]{3}{*}{$P$-value } & \multirow{2}{*}{\multicolumn{3}{|c|}{ All farms }} \\
\hline & \multicolumn{2}{|c|}{ A } & \multicolumn{2}{|c|}{ B } & \multicolumn{2}{|c|}{$\mathrm{C}$} & \multicolumn{2}{|c|}{$\mathrm{D}$} & & & & \\
\hline & $\mathrm{n}$ & $\%$ & $\mathrm{n}$ & $\%$ & $\mathrm{n}$ & $\%$ & $\mathrm{n}$ & $\%$ & & $\mathrm{n}$ & $\%$ & Mean \\
\hline Number of milking cows & $1,250^{\mathrm{a}}$ & & $1,250^{\mathrm{a}}$ & & $800^{\mathrm{b}}$ & & $640^{\mathrm{c}}$ & & $<0.001$ & & & 985 \\
\hline Milk production ( $\mathrm{kg} / \mathrm{cow}$ per day) & $36^{\mathrm{a}}$ & & $39^{\mathrm{a}}$ & & $44^{\mathrm{b}}$ & & $42^{\mathrm{b}}$ & & $<0.001$ & & & 40 \\
\hline Bulk tank SCC ${ }^{1}(\times 1,000$ cells $/ \mathrm{mL})$ & $240^{\mathrm{a}}$ & & $250^{\mathrm{a}}$ & & $168^{\mathrm{b}}$ & & $213^{\mathrm{a}}$ & & $<0.001$ & & & 218 \\
\hline Duration of sampling period (d) & 62 & & 31 & & 101 & & 67 & & & & & 65 \\
\hline All cases of clinical mastitis & 85 & & 64 & & 53 & & 64 & & & 266 & & \\
\hline Mild & 57 & 67 & 45 & 70 & 29 & 55 & 41 & 64 & & 172 & 65 & \\
\hline Moderate & 21 & 25 & 16 & 25 & 21 & 40 & 14 & 22 & & 72 & 27 & \\
\hline Severe & 7 & 8 & 3 & 5 & 3 & 6 & 9 & 14 & & 22 & 8 & \\
\hline Cases eligible for enrollment $^{2}$ & 73 & & 61 & & 48 & & 51 & & 0.086 & 233 & & \\
\hline Cases treated with intramammary ceftiofur & 55 & & 61 & & 34 & & 22 & & $<0.001$ & 172 & & \\
\hline Cases used in statistical analysis ${ }^{3}$ & 47 & & 45 & & 32 & & 19 & & 0.003 & 143 & & \\
\hline Severity & & & & & & & & & 0.349 & & & \\
\hline Mild & 34 & 72 & 32 & 71 & 18 & 56 & 11 & 58 & & 95 & 66 & \\
\hline Moderate & 13 & 28 & 13 & 29 & 14 & 44 & 8 & 42 & & 48 & 34 & \\
\hline Pre-treatment diagnosis & & & & & & & & & 0.001 & & & \\
\hline Gram-positive & 8 & 17 & 13 & 29 & 16 & 50 & 3 & 16 & & 40 & 28 & \\
\hline Gram-negative & 13 & 28 & 11 & 24 & 7 & 22 & 12 & 63 & & 43 & 30 & \\
\hline No growth & 26 & 55 & 21 & 47 & 9 & 28 & 4 & 21 & & 60 & 42 & \\
\hline Parity & & & & & & & & & 0.438 & & & \\
\hline First & 7 & 15 & 5 & 11 & 4 & 12 & 5 & 26 & & 21 & 15 & \\
\hline Second & 20 & 42 & 15 & 33 & 10 & 31 & 9 & 47 & & 54 & 38 & \\
\hline Third & 7 & 15 & 13 & 29 & 6 & 19 & 2 & 10 & & 28 & 19 & \\
\hline > Third & 13 & 28 & 12 & 27 & 12 & 38 & 3 & 16 & & 40 & 28 & \\
\hline Previous occurrence of $\mathrm{CM}^{4}$ & & & & & & & & & 0.029 & & & \\
\hline Yes & 11 & 23 & 18 & 40 & 5 & 16 & 9 & 47 & & 43 & 30 & \\
\hline No & 36 & 77 & 27 & 60 & 27 & 84 & 10 & 53 & & 100 & 70 & \\
\hline
\end{tabular}

․․․ ${ }^{1}$ Herd average for the last 3 months.

₹. $\quad{ }^{2}$ Cows with multiple quarters affected or antimicrobial therapy within $14 \mathrm{~d}$ were not eligible.

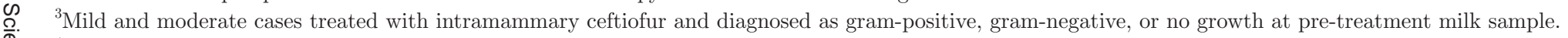

${ }^{4}$ During studied lactation. 
The average SCS at the DHIA test previous to the case was 3.6 and did not differ among farms $(P=0.503)$. However, the SCS at previous DHIA test from cows that experienced mild cases of $\mathrm{CM}$ was greater than those that experienced moderate cases (4.3 vs. 2.4; $P<$ 0.001; Table 3). The milk production of enrolled cows at the DHIA test previous to the case was $45.4 \mathrm{~kg} /$ cow per day and differed among farms $(P<0.001$; Table 3$)$.

\section{Characteristics of Treatment}

Duration of treatment was $4.8 \mathrm{~d}$, ranged from 1 to $15 \mathrm{~d}$ per case, and varied among farms $(P<0.001$; Table 3). Only 1 cow was treated for $1 \mathrm{~d}$ because she died before a second treatment could be administered. Duration of treatment was about $2 \mathrm{~d}$ less for farm A as compared with the other farms (Table 3). Producers tended to treat moderate cases for about one more day as compared with treatment of mild cases (5.4 vs. $4.6 \mathrm{~d}$; $P=0.049$; Table 3$)$. Most cows (94.1\%) received IMM treatment according to label specifications (one IMM treatment every $24 \mathrm{~h}$ for 2 to 8 consecutive days). The number of days to clinical cure was $5.4 \mathrm{~d}$ ( 2 to $15 \mathrm{~d}$ ), and did not vary among farms $(P=0.484$; Table 3$)$. Accordingly, milk was discarded for $7.7 \mathrm{~d}$ and did not differ among farms $(P=0.252$; Table 3$)$.

\section{Microbiological Results}

Most results of duplicate milk samples collected before treatment (PRE) were identical $(127 / 143)$; therefore, the criteria for non-matching duplicate samples were used for only $11 \%$ of samples (Table 1). Most cases of CM were caused by environmental pathogens. The most prevalent pathogens isolated in PRE milk samples were environmental streptococci (18\%), followed by Escherichia coli (10\%), and Klebsiella spp. (8\%) (Table 4). No Mycoplasma spp. were detected in pooled milk samples.

Microbiological diagnosis of the PRE samples was distributed as gram-negative $(30 \%)$, gram-positive $(28 \%)$, and no growth (42\%) and varied among farms $(P=0.001$; Table 2$)$. Fewer duplicate POST milk samples were identical (103/143) compared with PRE milk samples; therefore, the criteria for non-identical duplicate samples were used for $28 \%$ of the milk samples (Table 1). The number of cases with usable POST milk sample was decreased to 101 because milk samples were not collected $(\mathrm{n}=5)$, were contaminated $(\mathrm{n}=26)$, or because the cows were sold $(\mathrm{n}=6)$, dried $(\mathrm{n}=3)$, or died $(n=2)$ before the sample could be collected. Two POST samples diagnosed as mixed infection were included and considered as a treatment failure in the analysis of bacteriological cure. Most of the POST

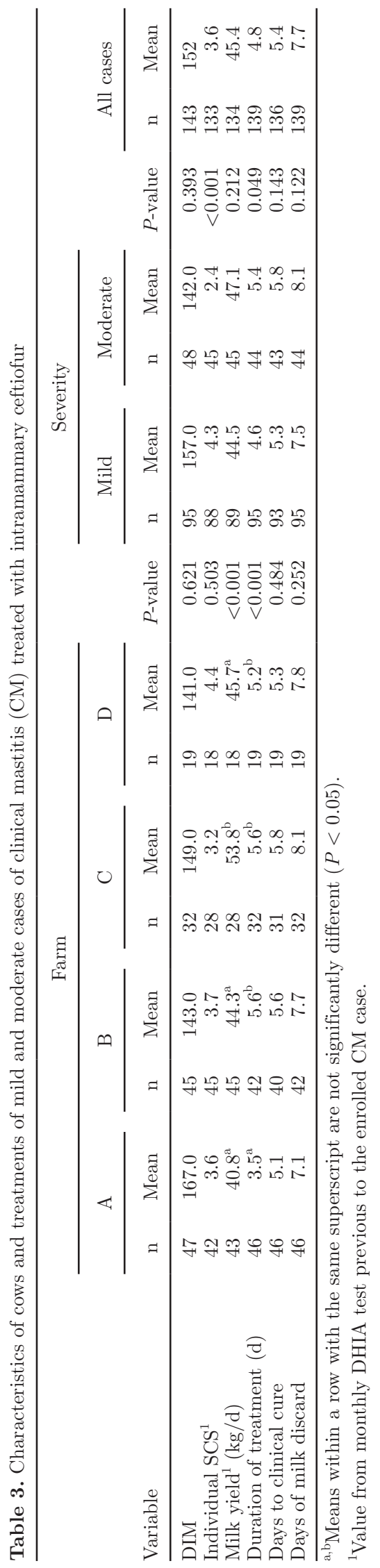


Table 4. Microbiological diagnosis of milk samples obtained from mild and moderate cases of clinical mastitis collected pre-treatment (PRE) or post-treatment (POST)

\begin{tabular}{|c|c|c|c|c|}
\hline \multirow{2}{*}{$\begin{array}{l}\text { Microbiological } \\
\text { diagnosis }\end{array}$} & \multicolumn{2}{|c|}{ PRE } & \multicolumn{2}{|c|}{ POST } \\
\hline & $\mathrm{n}$ & $\%$ & $\mathrm{n}$ & $\%$ \\
\hline Gram-negative & 43 & 30.1 & 7 & 4.9 \\
\hline Escherichia coli & 14 & 9.8 & 0 & \\
\hline Klebsiella spp. & 11 & 7.7 & 1 & 0.7 \\
\hline Enterobacter spp. & 8 & 5.6 & 0 & \\
\hline Serratia spp. & 7 & 4.9 & 5 & 3.5 \\
\hline Other gram-negative $^{1}$ & 3 & 2.1 & 1 & 0.7 \\
\hline Gram-positive & 40 & 28.0 & 14 & 9.8 \\
\hline Environmental streptococci & 25 & 17.5 & 9 & 6.3 \\
\hline Streptococcus dysgalactiae & 10 & 7.0 & 0 & \\
\hline Aerococcus viridians & 6 & 4.2 & 3 & 2.0 \\
\hline Lactococcus lactis & 3 & 2.1 & 1 & 0.7 \\
\hline Streptococcus equines & 2 & 1.4 & 0 & \\
\hline Streptococcus mitis & 2 & 1.4 & 0 & \\
\hline Streptococcus suis & 1 & 0.7 & 0 & \\
\hline Streptococcus salivarus & 1 & 0.7 & 0 & \\
\hline Enterococcus fecalis & 0 & & 1 & 0.7 \\
\hline Enterococcus durans & 0 & & 1 & 0.7 \\
\hline Enterococcus leuconostoc & 0 & & 1 & 0.7 \\
\hline Unidentified species & 0 & & 2 & 1.4 \\
\hline Other gram-positive ${ }^{2}$ & 9 & 5.6 & 5 & 3.5 \\
\hline CNS & 4 & 2.8 & 0 & \\
\hline Staphylococcus chromogenes & 2 & 1.4 & 0 & \\
\hline Staphylococcus simulans & 2 & 1.4 & 0 & \\
\hline Staphylococcus aureus & 1 & 0.7 & 0 & \\
\hline Streptococcus agalactiae & 1 & 0.7 & 0 & \\
\hline No growth & 60 & 42.0 & 78 & 54.5 \\
\hline Contaminated samples ${ }^{3}$ & 0 & 0 & 26 & 18.2 \\
\hline Missing samples & 0 & 0 & 16 & 11.2 \\
\hline Mixed infection ${ }^{3}$ & 0 & 0 & 2 & 1.4 \\
\hline Total & 143 & 100.0 & 143 & 100.0 \\
\hline
\end{tabular}

${ }^{1}$ Citrobacter spp., Pasteurella spp., and Pseudomonas spp. were coded as other gram-negative.

${ }^{2}$ Arcanobacterium pyogenes, Bacillus spp., Lactobacillus spp., and yeast were coded as other gram-positive.

${ }^{3}$ Pre-treatment milk samples that were contaminated or had mixed infections were excluded.

milk samples resulted in no bacterial growth. The most prevalent pathogens post-treatment were environmental Streptococcus and Serratia spp.

\section{Bacteriological Cure}

The overall proportion of bacteriological cure of enrolled quarters was $77.2 \%(78 / 101)$. The variables farm, severity, DIM at occurrence of CM, duration of treatment, and milk production at DHIA test previous to the case were not eligible for selection in the multivariate models for bacteriological cure $(P>0.25)$. Although parity was not unconditionally associated with bacteriological cure $(P=0.087)$, only $60.7 \%$ of cases occurring in cows with more than 3 lactations resulted in bacteriological cures as compared with $83.3 \%$ (first lactation), $81 \%$ (second lactation), and $89.5 \%$ (third lactation). Bacteriological cure by microbiological diagnosis at PRE was $75.0 \%$ gram-negative $(\mathrm{n}=28)$, $62.5 \%$ gram-positive $(\mathrm{n}=24)$, and $85.7 \%$ no growth
( $\mathrm{n}=49)$ and was not unconditionally associated with microbiological diagnosis at PRE $(P=0.08)$. However, when microbiological diagnosis was categorized as culture positive (either gram-positive or gram-negative), or culture negative (no growth), a tendency existed for bacteriological cure to be less for culture positive $(69.2 \%)$ as compared with culture negative $(85.7 \% ; P$ $=0.059)$. The proportion of bacteriological cures was greater than $80 \%$ for coliforms (E. coli, Klebsiella spp., and Enterobacter spp.) as compared with $61 \%$ for environmental Streptococcus spp. The pathogen with the least proportion of bacteriological cure was Serratia spp. $(16.7 \%$; $\mathrm{n}=6$; Table 5$)$.

Previous occurrence of $\mathrm{CM}$ in the studied lactation was unconditionally associated with bacteriological cure $(P<0.001)$. The proportion of enrolled quarters that resulted in bacteriological cure was greater for the first case of CM (86.5\%) as compared with cases that were preceded by previous cases of CM $(51.9 \%)$ during the studied lactation. Cases that resulted in bacterio- 
Table 5. Proportion of bacteriological cure for 101 cases of mild or moderate clinical mastitis by microbiological diagnosis pre-treatment

\begin{tabular}{|c|c|c|}
\hline $\begin{array}{l}\text { Pre-treatment } \\
\text { diagnosis }\end{array}$ & $\begin{array}{l}\text { Bacteriological cure } \\
\text { (n; \% in parentheses) }\end{array}$ & Total \\
\hline Gram-negative & $21(75.0)$ & 28 \\
\hline Escherichia coli & $9(90.0)$ & 10 \\
\hline Klebsiella spp. & $4(80.0)$ & 5 \\
\hline Enterobacter spp. & $5(100.0)$ & 5 \\
\hline Serratia spp. & $1(16.7)$ & 6 \\
\hline Other gram-negative ${ }^{1}$ & $2(100.0)$ & 2 \\
\hline Gram-positive & $15(62.5)$ & 24 \\
\hline Environmental streptococci & $11(61.1)$ & 18 \\
\hline Other gram-positive 2 & $4(80.0)$ & 5 \\
\hline CNS & $0(0.0)$ & 1 \\
\hline No growth ${ }^{3}$ & $42(85.7)$ & 49 \\
\hline Total & $78(77.2)$ & 101 \\
\hline
\end{tabular}

${ }^{1}$ Citrobacter spp., Pasteurella spp., and Pseudomonas spp. were coded as other gram-negative.

${ }^{2}$ Arcanobacterium pyogenes, Bacillus spp., and Lactobacillus spp. were coded as other gram-positive.

${ }^{3}$ Classified as spontaneous cure.

logical cures had lower SCS at the DHIA test previous to the case as compared with those that did not result in bacteriological cures (3.1 vs. $4.9 ; P=0.004$ ).

The final multivariate logistic model for bacteriological cure included only microbiological diagnosis pre-treatment and occurrence of previous cases of CM during the studied lactation (Table 6). Cows that experienced $\mathrm{CM}$ for the first time in the studied lactation were 7 times more likely to result in bacteriological cure compared with cows that had previous cases of CM in the studied lactation (Table 6). A tendency existed for cases that were culture positive (either gram-positive or gram-negative) to be 3 to 5 times less likely to result in bacteriological cure compared with cases from which pathogens were not recovered $(P=0.063$; Table 6$)$.

\section{Recurrence}

For the analysis of recurrence, 24 cases were excluded because the cow was dried $(n=9)$, died $(n=2)$, or was sold $(\mathrm{n}=13)$ before completing the 60 -d follow-up period or experiencing a recurrence. The overall proportion of recurrence of $\mathrm{CM}$ in cows was $21.8 \%$ (26/119). Of cows with recurrent cases, $46 \%$ occurred in a different quarter and $54 \%$ in the same quarter. Severity, previous occurrence of CM, microbiological diagnosis at PRE, SCS, and milk production at DHIA test previous to the case were not eligible for selection in the multivariate model for recurrence $(P>0.25)$. A tendency existed for the proportion of recurrent cases to increase with parity $(P=0.08)$ : lactation $1(6.2 \%, \mathrm{n}=16)$, lactation $2(18.4 \%, \mathrm{n}=49)$, lactation $3(20.8 \%, \mathrm{n}=24)$, and lactation $>3(36.7 \%, \mathrm{n}=30)$.

Recurrence of $\mathrm{CM}$ was unconditionally associated with DIM at occurrence of the CM case $(P=0.05)$. Cows that experienced recurrent cases were earlier in lactation $(105 \mathrm{~d})$ as compared with cows that did not experience a recurrent case $(140 \mathrm{~d})$. A tendency existed for shorter duration of treatment $(4.2 \mathrm{~d})$ for cows that experienced a recurrent case as compared with treatment duration $(5.1 \mathrm{~d})$ of cows that did not experience recurrence $(P=0.062)$. Recurrence of CM was unconditionally associated with bacteriological cure $(P=0.002)$. Most of the cows with enrolled quarters that experienced bacteriological cure did not recur $(87.3 \% ; \mathrm{n}=71)$, as compared with recurrence in cows that did not experience bacteriological cure $(57.1 \% ; \mathrm{n}=21)$.

Multivariate logistic model 1 for recurrence included farm as a forced variable, duration of treatment, and parity (Table 7). Older cows were more likely to have recurrences compared with first-lactation cows $(P=$ 0.029). Cows that were in third or greater lactation were 15.4 times more likely to experience recurrence as compared with cows in their first lactation. For every day of treatment duration, cows were 1.3 times less likely to have a recurrence $(P=0.07)$.

Multivariate logistic model 2 for recurrence included farm (forced) and bacteriological cure (Table 7). Cows that did not experience bacteriological cure were 8 times more likely to have a recurrence compared with those that experience bacteriological cure $(P=0.001$; Table 7).

Table 6. Final logistic regression model of risk factors for bacteriological cure for 101 cases of mild and moderate clinical mastitis (CM) after treatment with intramammary ceftiofur

\begin{tabular}{|c|c|c|c|c|c|c|}
\hline \multirow[b]{2}{*}{ Predictor } & \multirow[b]{2}{*}{$\beta$} & \multirow[b]{2}{*}{$\mathrm{SE}$} & \multirow[b]{2}{*}{$P$-value } & \multirow{2}{*}{$\begin{array}{l}\text { Odds } \\
\text { ratio }\end{array}$} & \multicolumn{2}{|c|}{$95 \% \mathrm{CI}$} \\
\hline & & & & & Lower & Upper \\
\hline Intercept & 0.83 & 0.27 & & & & \\
\hline Diagnosis pre-treatment & & & 0.063 & & & \\
\hline Gram-negative & -0.15 & 0.38 & & 0.4 & 0.10 & 1.34 \\
\hline Gram-positive & -0.67 & 0.38 & & 0.2 & 0.06 & 0.79 \\
\hline No growth & Reference & & & & & \\
\hline Occurrence of previous CM & & & $<0.001$ & & & \\
\hline No & 0.97 & 0.27 & & 7.1 & 2.39 & 20.93 \\
\hline Yes & Reference & & & & & \\
\hline
\end{tabular}


Table 7. Final logistic regression model of risk factors for recurrence of clinical mastitis (CM) for 119 cases of mild and moderate CM after treatment with intramammary ceftiofur (model 1); model 2 included bacteriological cure as a predictor $(\mathrm{n}=92)$

\begin{tabular}{|c|c|c|c|c|c|c|}
\hline \multirow[b]{2}{*}{ Predictor } & \multirow[b]{2}{*}{$\beta$} & \multirow[b]{2}{*}{$\mathrm{SE}$} & \multirow[b]{2}{*}{$P$-value } & \multirow{2}{*}{$\begin{array}{l}\text { Odds } \\
\text { ratio }\end{array}$} & \multicolumn{2}{|c|}{$95 \%$ CI } \\
\hline & & & & & Lower & Upper \\
\hline \multicolumn{7}{|l|}{ Model 1} \\
\hline Intercept & -0.272 & 0.837 & & & & \\
\hline Farm (forced) & & & 0.089 & & & \\
\hline A & -0.242 & 0.467 & 0.604 & & & \\
\hline B & 0.787 & 0.412 & 0.056 & & & \\
\hline $\mathrm{C}$ & Reference & & & & & \\
\hline $\mathrm{D}$ & 0.642 & 0.532 & 0.228 & & & \\
\hline Duration of treatment & -0.285 & 0.159 & 0.075 & & & \\
\hline Parity & & & 0.029 & & & \\
\hline First & Reference & & & & & \\
\hline Second & -0.099 & 0.429 & 0.817 & 3.59 & 0.41 & 31.74 \\
\hline Third & 0.126 & 0.506 & 0.804 & 4.50 & 0.45 & 44.85 \\
\hline$>$ Third & 1.353 & 0.464 & 0.004 & 15.36 & 1.64 & 143.93 \\
\hline \multicolumn{7}{|l|}{ Model 2} \\
\hline Intercept & -1.276 & 0.364 & & & & \\
\hline Farm (forced) & & & 0.092 & & & \\
\hline A & 0.394 & 0.509 & 0.439 & & & \\
\hline B & 1.101 & 0.515 & 0.021 & & & \\
\hline $\mathrm{C}$ & Reference & & & & & \\
\hline $\mathrm{D}$ & 0.179 & 0.626 & 0.774 & & & \\
\hline Bacteriological cure & & & 0.001 & & & \\
\hline No & 1.049 & 0.329 & 0.001 & 8.15 & 2.25 & 29.59 \\
\hline Yes & Reference & & & & & \\
\hline
\end{tabular}

\section{Retention Within the Herd}

During the 60 -d follow-up period, $87.4 \%$ of enrolled cows (125 of 143 cases) were retained in the herd. Cows remained in the herd either milking $(\mathrm{n}=115)$ or were dried off at the end of their lactation $(\mathrm{n}=10)$. Most animals that left the herd were sold $(\mathrm{n}=16)$, but 2 recently fresh cows died. Reasons reported for culling were mastitis $(\mathrm{n}=10)$, low milk production $(\mathrm{n}=2)$, and other reasons $(\mathrm{n}=4)$.

Variables that were not eligible for selection in the multivariate models for retention included farm, severity of the case, microbiological diagnosis of the CM case, duration of treatment, and previous SCS $(P>$ $0.25)$. Unconditional associations with retention were observed for parity, previous occurrence of CM, DIM at $\mathrm{CM}$ and previous test-day milk production. Younger cows were more likely to stay in the herd compared with older cows $(P=0.04)$. More than $90 \%$ of the animals with 3 or less parities $(n=103)$ remained in the herd, whereas only $75 \%$ of the animals with 4 or more parities $(\mathrm{n}=40)$ were retained. A greater proportion of animals that experienced CM for the first time (92\%) remained in the herd compared with animals that had previous cases of CM during the studied lactation $(76 \%$; $P=0.024)$. Cows that left the herd experienced CM later in lactation (194 DIM) as compared with those that remained in the herd (145 DIM; $P=0.048$ ). Cows that remained in the herd produced considerably more milk per day $(46.4 \mathrm{~kg})$ at the test date previous to the case as compared with cows that left the herd $(37.7 \mathrm{~kg}$; $P=0.003)$.

The final multivariate logistic model for retention within the herd included only farm (forced) and previous milk production. The effect of farm was not significant for retention $(P=0.54)$ but it was forced in the model because culling decisions are usually farm dependent. Every 1-kg increase of milk yield at the DHIA test before occurrence of $\mathrm{CM}$ increased the odds of the cow remaining in the herd by $9 \%$. Cows milking more than $50 \mathrm{~kg}$ of milk per day in the DHIA test previous to the CM case had more than $90 \%$ probability to remain in the herd (Figure 1).

\section{SCC Reduction}

The proportion of cows that experienced SCCR was $58.2 \%(71 / 122)$. The variables that were not eligible for selection in multivariate selection for SCCR included parity, severity of the case, microbiological diagnosis at PRE, DIM at occurrence of CM, duration of the treatment, and milk production at the DHIA test before occurrence of CM $(P>0.25)$. Unconditional associations with SCCR were found for farm, SCS at previous DHIA test, previous occurrence of CM, and bacteriological cure. The proportion of cows that experienced SCCR was unconditionally associated with farm ( $P$ 


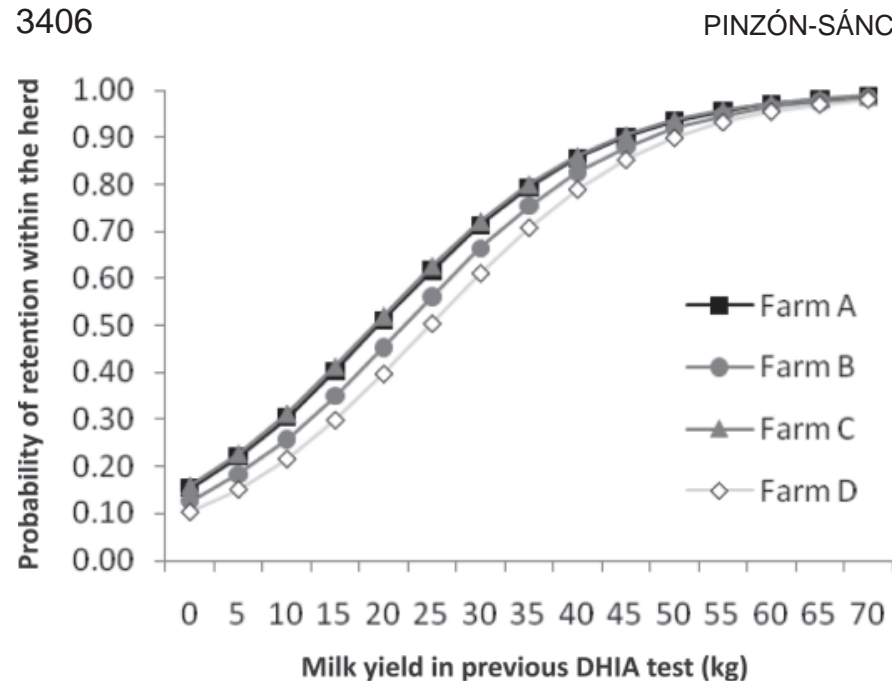

Figure 1. Probability of retention of the cow within the herd for various milk yields $(\mathrm{kg})$ in the previous DHIA test by farm.

$=0.04)$ and was $70.0 \%, 51.4 \%, 65.5 \%$, and $31.3 \%$ for farms A, B, C, and D, respectively. Reduction in SCC was observed in more animals that experienced the first case of CM in studied lactation $(66.7 \%$; $\mathrm{n}=90)$ as compared with those that had experienced previous cases of $\mathrm{CM}(34.4 \% ; \mathrm{n}=32)$. Cows that experienced a decrease in SCS after treatment were found to have lower previous SCS (2.9), as compared with cows that did not experience a decrease in SCC $(4.3 ; P=0.002)$. Somatic cell count reduction occurred more frequently for cows with enrolled quarters that experienced bacteriological cure $(95.0 \% ; \mathrm{n}=20)$ as compared with cows that did not $(25.9 \% ; \mathrm{n}=77 ; P<0.001)$.

Multivariate logistic model 1 for SCCR included SCS at previous DHIA test, occurrence of previous cases of $\mathrm{CM}$ in the studied lactation and the interaction between these 2 variables. The probability of experiencing SCCR was associated with the previous SCS and an interaction was observed with occurrence of a previous $\mathrm{CM}$ during studied lactation $(P=0.008$; Table 8$)$. For the first case of $\mathrm{CM}$ occurring in a cow, the probability of SCCR was around 65\%, regardless of the SCS at the previous DHIA test, whereas for recurrent cases the probability of having SCCR was greater than $70 \%$ when the SCS at the previous DHIA test was less than 4 and decreased steeply to about $10 \%$ as previous SCS increased to greater than 8 .

Multivariate logistic model 2 for SCCR included farm and bacteriological cure, and both were significantly associated with the probability of experiencing SCCR $(P<0.02$; Table 8$)$. Bacteriological cure had a strong effect on SCCR. Cows with enrolled quarters that did not experience bacteriological cure were 71.4 times less likely to be classified as having SCCR (Table 8). Farm B, C, and D were 4 to 43 times less likely to have SCCR when compared with farm A (Table 8).

\section{DISCUSSION}

In the United States, an increasing proportion of milk is produced in large herds. Often, on this type of

Table 8. Final logistic regression model of risk factors for SCC reduction for 115 cases of mild and moderate clinical mastitis $(\mathrm{CM})$ after treatment with intramammary ceftiofur (model 1$)$; model $2(\mathrm{n}=97)$ included bacteriological cure as a predictor

\begin{tabular}{|c|c|c|c|c|c|c|}
\hline \multirow[b]{2}{*}{ Predictor } & \multirow[b]{2}{*}{$\beta$} & \multirow[b]{2}{*}{ SE } & \multirow[b]{2}{*}{$P$-value } & \multirow{2}{*}{$\begin{array}{l}\text { Odds } \\
\text { ratio }\end{array}$} & \multicolumn{2}{|c|}{$95 \% \mathrm{CI}$} \\
\hline & & & & & Lower & Upper \\
\hline \multicolumn{7}{|l|}{ Model 1} \\
\hline Intercept & 1.95 & 0.69 & & & & \\
\hline $\mathrm{SCS}^{1}$ & -0.46 & 0.16 & 0.003 & & & \\
\hline \multicolumn{7}{|l|}{ PrevCM $^{2}$} \\
\hline No & -1.23 & 0.69 & 0.077 & & & \\
\hline Yes & Reference & & & & & \\
\hline Interaction SCS by PrevCM ${ }^{2}$ & 0.41 & 0.16 & 0.008 & & & \\
\hline PrevCM$^{2}:$ yes & & & & 0.6 & -0.61 & -0.30 \\
\hline PrevCM${ }^{2}$ : no & & & & 0.9 & -0.14 & 0.05 \\
\hline \multicolumn{7}{|l|}{ Model 2} \\
\hline Intercept & -1.22 & 0.55 & & & & \\
\hline Farm & & & 0.02 & & & \\
\hline A & Reference & & & & & \\
\hline B & -0.41 & 0.44 & & 0.3 & 0.08 & 1.13 \\
\hline $\mathrm{C}$ & 0.96 & 0.53 & & 1.2 & 0.24 & 5.60 \\
\hline $\mathrm{D}$ & -1.34 & 0.54 & & 0.1 & 0.02 & 0.57 \\
\hline Bacteriological cure & & & $<0.001$ & & & \\
\hline No & -2.15 & 0.55 & & 0.01 & 0.002 & 0.12 \\
\hline Yes & Reference & & & & & \\
\hline
\end{tabular}

${ }^{1}$ Somatic cell score at previous DHIA test.

${ }^{2}$ Occurrence of previous clinical mastitis in studied lactation. 
farm the owner is not actively engaged in milking the cows and the decision-making process for evaluation of treatment decisions is based on evaluation of current milking performance. The focus of this research was on the short-term outcomes after treatment of mild or moderate cases of $\mathrm{CM}$ occurring in single quarters of affected cows because this is the most common presentation of clinical mastitis and managers of large dairy herds often evaluate treatments over the short-term rather than determine the effect over the entire lactation. Post-treatment outcomes considered successful in this study were the clearance of pathogens after IMM treatment of the affected quarter, as assessed by bacteriological cure of the quarter, the response of SCC (at the cow level) to the threshold perceived as healthy $(<200,000$ cells $/ \mathrm{mL})$, the decrease in recurrent cases of CM (at the cow level), and retention of the cow in the herd. Several associations between risk factors and post-treatment outcomes identified in this study could help farmers to recognize cows that may respond to appropriate therapy, guide treatment decisions such as duration of therapy, or affect the decision to withhold antimicrobials from selected cows and ultimately improve milk quality.

Although farms that participated in this study were volunteers, characteristics and management practices were typical of larger modern freestall dairy farms operating in Wisconsin. Daily milk yield, and bulk tank SCC were similar to like-sized herds participating in DHIA programs in this region and it is likely that these results can be extrapolated to similar herds. Most of the mild and moderate cases of CM in this study were caused by environmental pathogens such as E. coli, Klebsiella spp., Serratia spp., CNS, and environmental streptococci. Except for a greater prevalence of Serratia spp., the distribution of pathogens observed in this study is typical of modern US dairy farms that have controlled mastitis caused by contagious pathogens (Smith et al., 1985; Makovec and Ruegg, 2003; Hoe and Ruegg, 2005; Milne et al., 2005).

Specific treatment protocols were not used as a criterion to enroll herds or cases in this study, because the objective was to observe post-treatment outcomes from protocols currently used on commercial dairy herds. Although all treatments were recorded, only cases treated with IMM ceftiofur were able to be used for statistical analysis because the number of treatments using other compounds was not sufficient for analysis. Ceftiofur is a broad-spectrum third-generation cephalosporin antimicrobial that inhibits bacterial cell wall synthesis by interfering with enzymes essential for peptidoglycan synthesis. Commercial IMM ceftiofur tubes are labeled for treatment of clinical mastitis caused by CNS, Streptococcus dysgalactiae, and E. coli. The reference population for the results of this study would, thus, include only cows with single-quarter infections that were treated with intramammary ceftiofur.

Absence of pathogens in PRE milk samples obtained from the enrolled quarter was the most common bacteriological diagnosis in this study $(42 \%)$ and is in agreement with other published studies that enrolled farms of this type (Roberson et al., 2004; Hoe and Ruegg, 2005; Lago, 2009). Although it has been previously reported that unfavorable conditions during storage in farm freezers may decrease viability of bacteria (Dinsmore et al., 1992), in the current study, the proportion of culture-negative samples from university laboratory results was similar to results obtained from fresh milk samples assessed on each farm using on-farm culture systems (45\%; data not shown). Absence of pathogens in milk samples from cases of CM could be the result of spontaneous clearance of pathogens (Smith et al., 1985) or the relatively short duration of infections caused by gram-negative bacteria (Sears et al. 1993).

Longer days to clinical cure $(5.4 \mathrm{~d})$ were observed in the current study compared with 3 to $4 \mathrm{~d}$ reported by other mastitis researchers (Hoe and Ruegg, 2005; Lago, 2009). The number of days until clinical cure was not included in the statistical models because most farmers administered IMM antimicrobials until clinical cure was observed; thus, days to clinical cure was highly correlated with duration of treatment. A farmer may have perceived clinical cure as a treatment success, but many of the cases reverted to a subclinical state, as observed by SCC remaining increased after treatment or the presence of bacteria in the POST milk samples.

Bacteriological cure is a more objective way to assess efficacy of mastitis therapy compared with observation of clinical cure; however, it is not practical to evaluate this outcome on most farms. Previous researchers have used a variety of sampling strategies to define bacteriological cure (Guterbock et al., 1993; Milne et al., 2005; McDougall et al., 2007). Despite the difficultly in comparing bacteriological cure among studies, the proportion of bacteriological cure observed in this study was reasonably consistent with previous research.

Culture-negative milk samples are typically excluded from evaluations of treatment outcomes, especially when the purpose of a trial is to evaluate antimicrobial therapy. The present study included a unique definition of spontaneous cure as a classification of bacteriological cure (when pathogens were absent in PRE and POST samples obtained from the affected quarter), whereas most previous studies excluded the cases where no pathogen was isolated from PRE samples. Few researchers have reported treatment outcomes for culture-negative cases (Guterbock et al. 1993; Roberson et al., 2004). In the current study, bacteriological 
cure for quarters where pathogens were not recovered in PRE sample was $85 \%$ and was similar to cures reported by Guterbock et al. (1993; 82\%) and Roberson et al. (2004; 100\%). Unless a farm is using an on-farm culture system, they do not typically have microbiological diagnosis before initiating treatment and, thus, treat many microbiologically negative cases using IMM antimicrobials. Therefore, the perception of treatment outcomes often includes both culture-negative and culture-positive cases. The inclusion of culture-negative cases in this study was an attempt to better evaluate outcomes from the complete spectrum of CM cases.

The overall proportion of bacteriological cure of enrolled quarters $(77.2 \%)$ observed in the current study was greater than previously reported by Bradley and Green (2009; 65\%), who combined data from 3 separate clinical trials of cephalosporin antimicrobials. A potential reason for the difference could be our use of a single sampling point to define bacteriological cure. This study was not designed as a clinical trial and untreated control animals were not included; thus, outcomes observed in this study are a result of both treatment and spontaneous cures. The lack of a control group makes it impossible to establish if successful outcomes were a result of antimicrobial treatment or a result of the cow's immune response before the antimicrobial was administered. Most mastitis research is conducted on commercial dairy farms and because of producer resistance, few studies include negative control groups. The inclusion of negative control groups in future studies would enhance our understanding of the benefits of antimicrobial therapy for various pathogen groups.

Researchers have reported a wide range of bacteriological cure (38 to 100\%) for clinical mastitis caused by gram-negative pathogens (Guterbock et al., 1993; Hoe and Ruegg, 2005; Bradley and Green, 2009). Overall bacteriological cure observed for gram-negative pathogens in this study (75\%) was within the ranges reported previously. Contradictory findings have been reported regarding the benefit of IMM antimicrobial therapy for clinical mastitis caused by gram-negative pathogens. The IMM use of antimicrobials appeared to have little efficacy against coliform pathogens, as greater bacteriological cures were observed in untreated groups as compared with treated groups (Guterbock et al., 1993; Roberson et al. 2004). However, most antimicrobials used in previous studies were not effective against gram-negative pathogens. Gram-negative pathogens are considered to be diverse in pathogenicity, duration of infection, and response to therapy (Hogan and Smith, 2003). The fewest bacteriological cures in the current study were observed for CM caused by Serratia spp. and this agrees with results of previous studies, indicating poor responses to antimicrobial therapy
(Bowman et al., 1986). It is generally recommended to avoid the use of antimicrobials when clinical mastitis is caused by nonresponsive pathogens (National Mastitis Council, 1999; Erskine et al., 2003). When Serratia spp. were excluded, $91 \%$ of gram-negative pathogens included in this study resulted in bacteriological cure after treatment; however, in the absence of a control group, it is impossible to distinguish between spontaneous or treatment cures.

In agreement with previous research (Owens et al., 1988; Sol et al., 2000; Bradley and Green, 2009), quarters that resulted in bacteriological cures came from cows that had lower SCS at the DHIA test previous to the case as compared with cows with enrolled quarters that did not result in bacteriological cures. Increased SCS may indicate that cows were chronically infected with subclinical mastitis before the development of the clinical case and others have reported that chronically infected cows have poorer response to therapy (Melchior et al., 2006). Similarly, cows that experienced previous cases of CM were less likely to experience bacteriological cure of the enrolled quarter. This finding is in agreement with other studies that have reported an association between previous cases of CM and the probability of reinfection (Houben et al., 1993; Steeneveld et al., 2008). Likewise, cows with quarters that did not experience bacteriological cure were more likely to have recurrent cases. Examination of the cow's history of clinical and subclinical mastitis (i.e., individual SCC from monthly test) before making a treatment decision should be recommended to direct mastitis therapy

Recurrence (or relapse) of CM has been described by different researchers as another case of clinical mastitis in the same cow, in the same quarter, or by the same pathogen (Wenz et al., 2005; Apparao et al., 2009; Schukken et al., 2009). The interval used to define a new case (rather than a recurrence) varies among studies ranging from 8 to $90 \mathrm{~d}$ or longer (Wenz et al., 2005; Bar et al., 2007; Apparao et al., 2009; Schukken et al., 2009). Researchers also differ in defining when the interval begins. It may be counted from the day of the diagnosis of clinical mastitis, from the last day of treatment, or from the last day of the withholding period (Wenz et al., 2005; Apparao et al., 2009; Schukken et al., 2009). Based on the economic importance to producers, we used a cow-level definition of recurrence (another case of clinical mastitis in the same cow, independently of quarter or pathogen). Producers often focus on economic losses due to discarded milk, regardless of the quarter affected. However, recording quarter and pathogen is useful for future decisions. In some instances, drying off a chronically infected mammary gland quarter could be a more optimal treatment as compared with repetitive treatments of glands that are 
unlikely to cure. The recognition of recurrence of CM is dependent upon the detection level of the herd and is especially affected by the use of forestripping during pre-milking cow preparation. All herds included in this study practiced forestripping and the proportion of recurrence observed ( $18 \%$ within $60 \mathrm{~d}$ post-treatment) was similar to that in previous reports $[17 \%$ within 30 $\mathrm{d}$ reported by Hoe and Ruegg (2005) and $23 \%$ within 90 d reported by Wenz et al. (2005)].

Similar to results of Wenz et al., (2005), cows with quarters that did not experience bacteriological cure were more likely to experience a recurrent case of CM. It is interesting to note that approximately $45 \%$ of the recurrent cases occurred in a different quarter, yet the failure to experience bacteriological cure of the enrolled quarter was a strong predictor of recurrence at the cow level. It is likely that the relationship between bacteriological cure and recurrence at the quarter level is even greater than indicated in this study.

Most of the animals that left the herd were culled rather than died. Culling decisions are directly affected by diseases (such as clinical mastitis) that result in marked decreases in milk production (Gröhn et al., 1998; Gröhn et al., 2005; Hadley et al., 2006). In this instance, milk production was the primary risk factor associated with retention of a cow within the herd. Cows that produced less than $20 \mathrm{~kg}$ of milk per day at the previous DHIA test had less than $50 \%$ probability of remaining in the herd. Herds included in this study were large commercial farms with a ready supply of replacement heifers. Other researchers have previously reported that greater milk yield was protective against culling (Gröhn et al., 1998).

Somatic cell count reduction below 200,000 cells/ $\mathrm{mL}$ is another desired outcome after treating mild and moderate cases of clinical mastitis. Somatic cell counts over 200,000 cells $/ \mathrm{mL}$ are often used to define subclinical mastitis and this threshold is used in US DHIA reports to identify cows suspected of having subclinical mastitis. Because characterization of shortterm outcomes was the objective of this study, only one test after $21 \mathrm{~d}$ had elapsed between treatment and the DHIA test was used. This test could have been either the first or the second DHIA test after enrollment of the case and tests that occur later are more likely to be below the threshold.

In the present study, the SCC response of the cow after treatment of CM caused by gram-negative pathogens was very similar to cases where no pathogen was recovered. Although $63 \%$ of cows with CM in a quarter caused by gram-negative pathogens or no growth had SCC below 200,000 cells $/ \mathrm{mL}$, only $44 \%$ of cows with quarter cases caused by gram-positive bacteria reached this level. Others have previously reported similarities between gram-negative pathogens and no growth, in terms of SCC patterns and milk production losses after CM case (Haas et al., 2004; Gröhn et al., 2004).

The interaction between the SCC before the case and occurrence of previous cases of $\mathrm{CM}$ on the SCCR observed in this study was very interesting. For cows experiencing the first case of $\mathrm{CM}$, the probability of SCCR was around 65\%, regardless of the previous SCC, whereas for cows that had previous CM cases, the probability of SCCR was greater when previous SCC was below 200,000 cells/mL and decreased steeply as the SCC increased. Similar to results of Nyman et al. (2010), low SCC at the test day before CM lowered the risk of having SCC $>200,000$ cells $/ \mathrm{mL}$ after the case, probably indicating the absence of subclinical mastitis. The duration of subclinical infection after treatment of $\mathrm{CM}$ has not been well reported for the variety of pathogens observed in this study.

\section{CONCLUSIONS}

Characterization of selected post-treatment outcomes of mild and moderate clinical mastitis occurring in single mammary quarters was performed and risk factors associated with these outcomes were identified. Affected quarters were more likely to have bacteriological cure when cows were experiencing $\mathrm{CM}$ for the first time in the lactation and when no pathogen was recovered from the PRE quarter milk sample. When the quarter experienced bacteriological cure, the cow was less likely to experience recurrence of $\mathrm{CM}$ and was more likely to have SCC below 200,000 cells/mL posttreatment. When SCC before CM was $>200,000$ cells/ $\mathrm{mL}$ the probability of the cow experiencing SCCR after treatment was decreased. Retention of the cow within the herd for the 60-d follow-up period was strongly associated with milk yield. Assessment of bacteriological cure on farm is not feasible for many farms; however, post-treatment outcomes, such as recurrence and SCCR, are strongly associated with bacteriological cure and, when monitored, can be used to help determine if a treatment has been successful. Information about the etiology of CM, history of clinical and subclinical (i.e., SCC) mastitis, and parity are useful to review when making strategic treatment decisions.

\section{REFERENCES}

Andersen, S., I. R. Dohoo, R. Olde Riekerink, and H. Stryhn, and Mastitis Research Workers' Conference. 2010. Diagnosing intramammary infections: Evaluating expert opinions on the definition of intramammary infection using conjoint analysis. J. Dairy Sci. 93:2966-2975.

Apparao, M. D., P. L. Ruegg, A. Lago, S. Godden, R. Bey, and K. Leslie. 2009. Relationship between in vitro susceptibility test re- 
sults and treatment outcomes for gram-positive mastitis pathogens following treatment with cephapirin sodium. J. Dairy Sci. 92:2589-2597.

Bar, D., Y. T. Gröhn, G. Bennett, R. N. Gonzalez, J. A. Hertl, H. F. Schulte, L. W. Tauer, F. L. Welcome, and Y. H. Schukken. 2007. Effect of repeated episodes of generic clinical mastitis on milk yield in dairy cows. J. Dairy Sci. 90:4643-4653.

Barkema, H. W., Y. H. Schukken, and R. N. Zadoks. 2006. Invited review: The role of cow pathogen and treatment regimen in the therapeutic success of bovine Staphylococcus aureus mastitis. J. Dairy Sci. 89:1877-1895.

Bowman, G. L., W. D. Hueston, G. J. Boner, J. J. Hurley, and J. E. Andreas. 1986. Serratia liquefaciens mastitis in a dairy herd. J. Am. Vet. Med. Assoc. 189:913-915.

Bradley, A. J., and M. J. Green. 2009. Factors affecting cure when treating bovine clinical mastitis with cephalosporin-based intramammary preparations. J. Dairy Sci. 92:1941-1953.

Constable, P. D., and D. E. Morin. 2003. Treatment of clinical mastitis using antimicrobial susceptibility profiles for treatment decisions. Vet. Clin. North Am. Food Anim. Pract. 19:139-155.

de Haas, Y., R. F. Veerkamp, H. W. Barkema, Y. T. Gröhn, and Y. H. Schukken. 2004. Associations between pathogen-specific cases of clinical mastitis and somatic cell count patterns. J. Dairy Sci. 87:95-105.

Deluyker, H. A., S. N. Van Oye, and J. F. Boucher. 2005. Factors affecting cure and somatic cell count after pirlimycin treatment of subclinical mastitis in lactating cows. J. Dairy Sci. 88:604-614.

Dinsmore, R. P., P. B. English, R. N. Gonzalez, and P. M. Sears. 1992. Use of augmented cultural techniques in the diagnosis of the bacterial cause of clinical bovine mastitis. J. Dairy Sci. 75:2706-2712.

Erskine, R. J., S. Wager, and F. J. DeGraves. 2003. Mastitis therapy and pharmacology. Vet. Clin. North Am. Food Anim. Pract. 19:109-138.

Gröhn, Y. T., S. W. Eicker, V. Ducrocq, and J. A. Hertl. 1998. Effect of disease on the culling of Holstein dairy cows in New York State. J. Dairy Sci. 81:966-978.

Gröhn, Y. T., R. N. González, D. J. Wilson, J. A. Hertl, G. Bennett, H. Schulte, and Y. H. Schukken. 2005. Effect of pathogen-specific clinical mastitis on herd life in two New York State dairy herds. Prev. Vet. Med. 71:105-125.

Gröhn, Y. T., D. J. Wilson, R. N. González, J. A. Hertl, H. Schulte, G. Bennett, and Y. H. Schukken. 2004. Effect of pathogen-specific clinical mastitis on milk yield in dairy cows. J. Dairy Sci. 87:3358-3374.

Guterbock, W. M., A. L. Van Eenennaam, R. J. Anderson, I. A. Gardner, J. S. Cullor, and C. A. Holmberg. 1993. Efficacy of intramammary antibiotic therapy for treatment of clinical mastitis caused by environmental pathogens. J. Dairy Sci. 76:3437-3444.

Hadley, G. L., C. A. Wolf, and S. B. Harsh. 2006. Dairy cattle culling patterns, explanations, and implications. J. Dairy Sci. 89:22862296.

Hill, A. E., A. L. Green, B. A. Wagner, and D. A. Dargatz. 2009. Relationship between herd size and annual prevalence of and primary antimicrobial treatments for common diseases on dairy operations in the United States. Prev. Vet. Med. 88:264-277.

Hoe, F. G. H., and P. L. Ruegg. 2005. Relationship between antimicrobial susceptibility of clinical mastitis pathogens and treatment outcome in cows. J. Am. Vet. Med. Assoc. 227:1461-1468.

Hogan, J., and K. L. Smith. 2003. Coliform mastitis. Vet. Res. 34:507-519.

Houben, E. H. P., A. A. Dijkhuizen, J. A. M. Van Arendonk, and R. B. M. Huirne. 1993. Short- and long-term production losses and repeatability of clinical mastitis in dairy cattle. J. Dairy Sci. $76: 2561-2578$.

Lago, J. A. 2009. Efficacy of on-farm programs for the diagnosis and selective treatment of clinical and subclinical mastitis in dairy cattle. PhD Dissertation. University of Minnesota, Minneapolis.

Makovec, J. A., and P. L. Ruegg. 2003. Results of milk samples submitted for microbiological examination in Wisconsin from 1994 to 2001. J. Dairy Sci. 86:3466-3472.
McDougall, S., D. G. Arthur, M. A. Bryan, J. J. Vermunt, and A. M. Weir. 2007. Clinical and bacteriological response to treatment of clinical mastitis with one of three intramammary antimicrobials. N. Z. Vet. J. 55:161-170.

Melchior, M. B., H. Vaarkamp, and J. Fink-Gremmels. 2006. Biofilms: A role in recurrent mastitis infections? Vet. J. 171:398-407.

Milne, M. H., A. M. Biggs, D. C. Barrett, F. J. Young, S. Doherty, G. T. Innocent, and J. L. Fitzpatrick. 2005. Treatment of persistent intramammary infections with Streptococcus uberis in dairy cows. Vet. Rec. 157:245-250.

NMC. 1999. Laboratory Handbook on Bovine Mastitis. National Mastitis Council, Verona, WI.

Nyman, A. K., U. Emanuelson, and K. Persson Waller. 2010. How may cow factors influence the long term success of antimicrobial treatment of clinical mastitis? Mastitis Research into Practice. Proceedings of the 5th IDF Mastitis Conference. Christchurch, New Zealand. VetLearn, Wellington, New Zealand.

Owens, W. E., J. L. Watts, R. L. Boddie, and S. C. Nickerson. 1988 Antibiotic treatment of mastitis: Comparison of intramammary and intramammary plus intramuscular therapies. J. Dairy Sci. 71:3143-3147.

Palta, M. 2003. Quantitative Methods on Population Health: Extensions of Ordinary Regression. John Wiley and Sons, Hoboken, NJ.

Pol, M., and P. L. Ruegg. 2007. Treatment practices and quantification of antimicrobial drug usage in conventional and organic dairy farms in Wisconsin. J. Dairy Sci. 90:249-261.

Pyörälä, S. H. K., and E. O. Pyörälä. 1998. Efficacy of parentera administration of three antimicrobial agents in treatment of clinical mastitis in lactating cows: 487 cases (1989-1995). J. Am. Vet. Med. Assoc. 212:407-412.

Roberson, J. R., L. D. Warnick, and G. Moore. 2004. Mild to moderate clinical mastitis: Efficacy of intramammary amoxicillin, frequent milk-out, a combined intramammary amoxicillin, and frequent milk-out treatment versus no treatment. J. Dairy Sci. 87:583-592.

SAS Institute. 2008. SAS/STAT User's Guide. Version 9.2. SAS Inst Inc., Cary, NC.

Schukken, Y. H., J. Hertl, D. Bar, G. J. Bennett, R. N. Gonzalez, B. J. Rauch, C. Santisteban, H. F. Schulte, L. Tauer, F. L. Welcome, and Y. T. Gröhn. 2009. Effects of repeated gram-positive and gram-negative clinical mastitis episodes on milk yield loss in Holstein dairy cows. J. Dairy Sci. 92:3091-3105.

Sears, P. M., R. N. Gonzalez, D. J. Wilson, and H. R. Han. 1993. Procedures for mastitis diagnosis and control. Vet. Clin. North Am. Food Anim. Pract. 9:445-468.

Silva, B. O., D. Z. Caraviello, A. C. Rodrigues, and P. L. Ruegg. 2005. Evaluation of Petrifilm for the isolation of Staphylococcus aureus from milk samples. J. Dairy Sci. 88:3000-3008.

Smith, K. L., D. A. Todhunter, and P. S. Schoenberger. 1985. Environmental mastitis: Cause, prevalence, prevention. J. Dairy Sci. 68:1531-1553.

Sol, J., O. C. Sampimon, H. W. Barkema, and Y. H. Schukken. 2000. Factor associated with cure after therapy of clinical mastitis caused by Staphylococcus aureus. J. Dairy Sci. 83:278-284.

Sol, J., O. C. Sampimon, J. J. Snoep, and Y. H. Schukken. 1997. Factors associated with bacteriological cure during lactation after therapy for subclinical mastitis caused by Staphylococcus aureus. J. Dairy Sci. 80:2803-2808.

Steeneveld, W., H. Hogeveen, H. W. Barkema, J. Van den Broek, and R. B. M. Huirne. 2008. The influence of cow factors on the incidence of clinical mastitis in dairy cows. J. Dairy Sci. 91:13911402.

Wenz, J. R., F. B. Garry, J. E. Lombard, R. Elia, D. Prentice, and R. P. Dinsmore. 2005. Short communication: Efficacy of parenteral ceftiofur for treatment of systemically mild clinical mastitis in dairy cattle. J. Dairy Sci. 88:3496-3499. 